\title{
an Overview of The Fecal Waste Management City of Surabaya: Challenges and Opportunities to Improve Services
}

\author{
Zulfi Hadianto ${ }^{1, *}$, Syafrudin Syafrudin ${ }^{2}$, and Sunarsih Sunarsih ${ }^{3}$ \\ ${ }^{1}$ Magister Program of Environmental Science, School of Postgraduate Studies, Diponegoro University, Semarang - Indonesia \\ ${ }^{2}$ Department of Environmental Engineering, Faculty of Engineering, Diponegoro University, Semarang - Indonesia \\ ${ }^{2}$ Faculty of Science and Mathematics, Diponegoro University, Semarang - Indonesia
}

\begin{abstract}
The increasing number of residents in Surabaya City which has been continuously happening for the last 3 years has put pressure on environmental quality and sanitation. Each year in the coastal and riverbanks areas increased the domestic waste of the community resulting in decreased environmental quality. This study aims to review the management of stool waste in Surabaya City from 3 (three) aspects, namely: management aspect, social aspect of society and regulation aspect. The results of the demonstration to improve the management of stool waste in the city of Surabaya required a breakthrough in the service of stool waste management by implementing scheduled sludge service
\end{abstract}

Keyword : Fecal Waste Treatment, scheduled sludge service

\section{Introduction}

During the last 3 (three) years (2014 - 2016), the city of Surabaya experienced an increase in the population every year [1]. Up to 2016, the total population in the city of Surabaya was 3,016,653 inhabitants where an increase in the population of the city of Surabaya was not only caused by birth factors but also by the presence of immigrants from outside the area who settled in Surabaya.

Increased population must be balanced with improved access and sanitation services. Urban sanitation services such as improved quality management services for wastewater and sludge that are better quality will support urban economic growth, reduce health risks, and protect the environment and will achieve the goals of sustainable development.

Creating proper and healthy sanitation for its citizens is a challenge for every Local Government in Indonesia, because as we all know that sanitation is a basic need of the community that must be met to improve the level of community welfare. Sanitation as explained in the Presidential Regulation of the Republic of Indonesia Number 185 of 2014 concerning Acceleration of Provision of Drinking Water and Sanitation is all efforts made to ensure the realization of conditions that meet health requirements through sanitation development. In general, sanitation is the activity of providing controlled and safe facilities and services for the disposal of urine and feces. Inadequate sanitation is a major cause of disease throughout the world and sanitation is known to have a positive impact on health both in the household and in society in general.

Good sanitation is an absolute thing that must be fulfilled in order to obtain a healthy community life. One of the few sanitation facilities that should be owned by a family is the facility to carry out defecation activities equipped with septic tanks and infiltration tanks. The importance of these facilities is closely related to the implementation of fecal waste management which is closely related to environmental and public health problems. The decrease in water quality and sanitation quality caused by the disposal of human feces can be overcome, eliminated, suppressed or reduced if the factors causing the problem are reduced in content, kept away from human contact [2].

This paper aims to find out again the management of fecal waste in Surabaya City from 3 (three) aspects, namely management aspects, social aspects and institutional aspects. And based on some of these aspects, a conclusion can be drawn and become the basis for improving stool waste management services in the city of Surabaya as the mission being carried out by the Surabaya City Government to establish environmental and settlement facilities and infrastructure that are environmentally friendly.

\section{Management of Fecal Waste of Surabaya City}

Managing waste in an urban area has three main aspects that are interrelated in each aspect. These 3 (three) aspects 
are: technical aspects of processing, institutional aspects and social aspects. These three aspects must exist and have a good working synergy with each other. To see how the city of Surabaya in managing the fecal waste generated by the community, then conducted a study of 3 (three) aspects as previously explained.

\subsection{Technical Aspects of Fecal Waste Management}

The existing sanitation system in the Surabaya City area includes local processing systems (on-site systems) and centralized systems (off-site systems). Residential areas generally use an on-site system, where bathrooms / toilets are equipped with septic tanks and if the tank is full, suction trucks will be suctioned and then processed at the available treatment plants before being discharged to the receiving water body.

In addition to the on-site system, a mixed system of on-site and off-site sanitation is also carried out where the discharge from the bathroom / WC is immediately discharged to the pipeline leading to the wastewater treatment plant with a communal system. In some areas in the city of Surabaya, wastewater from the bathroom, kitchen and washing area flows directly into the river body.

There are several communal systems in several residential areas, mostly built by the Surabaya City Government and East Java Provincial Public Works and Spatial Planning Office as the initial implementation of the intermediate system. The system used is modular IPAL, MCK++ and public latrines with processing facilities. Based on data from the Surabaya City Environmental Service, there are around 40 communal wastewater treatment facilities in the city of Surabaya [3].

Since 1991, the Surabaya City Government has operated an IPLT (Sewage Treatment Plant) in Keputih. IPLT is a technology that is used to improve the sewage disposal system that comes from the community. IPLT uses a biological system with an oxidation pond equipped with a motor and has a maximum processing capacity of $400 \mathrm{M}^{3}$ / day. Currently Keputih IPLT receives about 100 $\mathrm{m}^{3}$ of sewage sludge every day. Fecal waste is collected from septic tanks from all of Surabaya with privately operated fecal tank cars / fecal dewatering services that have been granted permission from the Surabaya City Sanitation and Landscaping Service (DKP). Each tank car has a capacity of $\pm 5 \mathrm{~m}^{3}$ and the average amount that operates every day is 50 car units [4].

The performance of the sludge treatment facility depends on the supply of sludge processed every day. A sludge treatment facility has been designed based on a certain design capacity so that it is expected to produce an effluent which will then be returned to the environment and is expected to meet applicable requirements and not pollute the environment.

Even though Surabaya City already has a sludge treatment facility, it does not automatically make the community use the facilities already owned. This is one of the obstacles faced in processing sludge in processing facilities. With the small utilization of sludge treatment facilities by the community causing a lack of supply of fecal sludge to be processed so as not to meet the processing design capacity.

Based on research that has been carried out at Keputih Surabaya's Sludge Treatment Plant (IPLT), the actual volume of sludge is only $137 \mathrm{~m}^{3}$ from a design capacity of $400 \mathrm{~m}^{3}$. The lack of feces sludge to be managed has an effect on the waste treatment process in Keputih IPLT so as to produce effluents that are not in accordance with the required quality standards as stipulated in the East Java Governor Regulation Number 72 of 2013 concerning quality standards for domestic wastewater. Therefore, we need a performance evaluation and optimization recommendation to improve the performance of the processing unit in Keputih IPLT in processing the volume of sludge that is served, so that the quality of effluent can meet the quality standards. [5].

\subsection{Social Aspects in Managing Faecal Waste Management}

The success of managing a domestic waste cannot be separated from the care and participation of the community in the initial management of waste. There are facilities and facilities to accommodate and manage domestic waste in every household.

Based on data compiled by the Surabaya City Environmental Service in the 2016 Surabaya City Environmental Management Information Report, obtained data on defecation facilities owned by households in each sub-district in the city of Surabaya as presented in table 1.

Table 1. Number of households and facilities for defecation

\begin{tabular}{|c|c|c|c|c|}
\hline \multirow{2}{*}{ Districts } & \multirow{2}{*}{ Number of } & \multicolumn{3}{|c|}{ Defecation Facility } \\
\cline { 3 - 5 } & Household & Own & Jointly & River \\
\hline Sukomanunggal & 31.484 & 29.902 & 680 & 902 \\
\hline Tandes & 28.333 & 27.470 & 797 & 66 \\
\hline Asemrowo & 13.207 & 11.696 & 229 & 1282 \\
\hline Benowo & 18.115 & 17.727 & 6 & 382 \\
\hline Pakal & 15.417 & 15.282 & 5 & 130 \\
\hline Lakarsantri & 17.480 & 17.474 & 6 & 0 \\
\hline Sambikerep & 18.905 & 18.839 & 66 & 0 \\
\hline Genteng & 19.433 & 16.767 & 2033 & 643 \\
\hline Tegalsari & 33.032 & 30.917 & 1802 & 313 \\
\hline Bubutan & 32.763 & 30.858 & 698 & 1207 \\
\hline Simokerto & 31.056 & 29.272 & 423 & 1361 \\
\hline Pabean & 25.366 & 24.661 & 281 & 424 \\
\hline Cantikan & & & & \\
\hline Semampir & 53.240 & 47.612 & 973 & 4655 \\
\hline Kembangan & 36.214 & 33.291 & 1641 & 1282 \\
\hline Bulak & 12.958 & 12.090 & 331 & 537 \\
\hline Kenjeran & 44.932 & 43.855 & 711 & 366 \\
\hline Tambaksari & 70.963 & 67.962 & 1781 & 1220 \\
\hline Gubeng & 45.387 & 43.662 & 405 & 1074 \\
\hline Rungkut & 33.956 & 32.703 & 320 & 337 \\
\hline Tenggiis & 18.058 & 16.594 & 1158 & 306 \\
\hline Mejoyo & & & & 0 \\
\hline Gunung Anyar & 17.072 & 16.572 & 0 & 500 \\
\hline Sukolilo & 33.470 & 32.780 & 141 & 549 \\
\hline Mulyorejo & 27.071 & 26.809 & 74 & 188 \\
\hline Sawahan & 62.464 & 61.310 & 261 & 893 \\
\hline Wonokromo & 51.145 & 47.462 & 1847 & 1836 \\
\hline Karangpilang & 22.737 & 22.518 & 102 & 117 \\
\hline
\end{tabular}




\begin{tabular}{|c|c|c|c|c|}
\hline \multirow{2}{*}{ Districts } & Number of & \multicolumn{3}{|c|}{ Defecation Facility } \\
\cline { 3 - 5 } & Household & Own & Jointly & River \\
\hline Dukuh Pakis & 18.899 & 18.869 & 0 & 30 \\
\hline Wiyung & 21.376 & 21.358 & 18 & 0 \\
\hline Gayungan & 14.262 & 13.881 & 381 & 0 \\
\hline Wonocolo & 24.553 & 23.807 & 89 & 657 \\
\hline Jambangan & 15.455 & 15.312 & 143 & 0 \\
\hline \multicolumn{5}{|l|}{} \\
Sumber : [3] & 908.803 & 869.312 & 17.402 & 21.257 \\
\hline
\end{tabular}

Based on these data, it can be described how the behavior of people in the city of Surabaya in defecating activities. Based on these data $96 \%$ of households in the city of Surabaya already have defecation facilities, but based on these data, there are still $2 \%$ of households that use the river as a facility for defecation. This condition is very concerning because if it is assumed that each household has 4 family members, it is estimated that there are still 85,028 people who dispose of stool waste directly into the river.

The Surabaya City Government through the Health Office conducted a study to understand the condition of sanitation facilities and behaviors that have a risk to public health. The results of a study conducted to analyze the Environmental Health Risk Assessment on stool wastewater disposal facilities owned illustrate the level of concern / knowledge and understanding of fecal waste management can be said to be less satisfactory. For example, $57.30 \%$ of septic tanks owned by a family are more than 10 years old [6]. This condition must certainly be of particular concern because the septic tank that is more than 10 years old is likely to have leaked and the waste water contained in it has seeped into the soil.

In addition, the Surabaya City community did not routinely empty their own septic tanks, where as many as $29 \%$ of households had never drained septic tanks, $19 \%$ of households had septic tanks drained more than 5 years ago, $34 \%$ of households had drained deep tanks in the past 1 - 5 years and $17 \%$ of households did not know whether they had already drained or not [6].

\subsection{Institutional Aspect in Managing Faecal Waste Management}

Technically, the management of fecal waste is carried out by the regional technical implementation unit (UPTD) of the Keputih Sewage Treatment Plant (IPLT) which is under the auspices of the Surabaya City Sanitation and Landscaping Service.

Regarding the management of fecal waste, the Surabaya City Government currently only regulates the levy tariff for the processing of liquid waste in the form of feces, which is regulated in Regional Regulation Number 1 of 2016 concerning Retribution of Liquid Waste Processing in Feces Forms. The principles and targets in determining levies tariffs are based on the objective of partially covering the cost of treating wastewater services in the form of fecal waste in the sewage treatment plant. The fee referred to consists of operational, maintenance and capital costs.

In addition to the levy tariff, Surabaya City does not yet have a law that has the substance that regulates socialization and calls to periodically suck up sludge in septic tanks.

\section{Discussion}

Feces and liquid waste are waste materials that arise due to human life, in addition to rainwater as a component of liquid waste that arises naturally from natural activities. Stool is a waste material that is released from the human body through the anus and is a remnant of the process of food digestion along the digestive tract system [2].

Humans in normal conditions are expected to produce about 83 grams of feces and 970 grams of urine in one day, which is mostly in the form of water consisting of organic substances ( $20 \%$ for feces and $2.5 \%$ for urine) and substances inorganic substances such as nitrogen, phosphoric acid, sulfur and so on [7]. Estimates of fecal composition and urine can be seen in table 2 .

Table 2. Composition of feces and urine

\begin{tabular}{ccc}
\hline Component & $\begin{array}{c}\text { The content } \\
\text { in the stool } \\
(\mathbf{\%})\end{array}$ & $\begin{array}{c}\text { The content } \\
\text { in the urine } \\
(\mathbf{\%})\end{array}$ \\
\hline Water & $66-80$ & $93-96$ \\
Organic Materials & $88-97$ & $65-85$ \\
Nitrogen (from dry weight) & $5-7$ & $15-19$ \\
Phosphor ( $\mathrm{P}_{2} \mathrm{O}_{5}$ ) (from dry & $3-5,4$ & $2,5-5$ \\
$\quad$ weight) & & \\
Potassium (as $\mathrm{K}_{2} \mathrm{O}$ ) (from & $1-2,5$ & $3-4,5$ \\
$\quad$ dry weight) & & \\
Carbon (from dry weight) & $40-55$ & $11-17$ \\
Calsium (as CaO) (from dry & $4-5$ & $4,5-6$ \\
$\quad$ weight) & & \\
C/N ratio (from dry weight) & $5-10$ & - \\
Source : $[8]$
\end{tabular}

Table 3. Quantity of feces and urine

\begin{tabular}{lcc}
\hline \multirow{2}{*}{ Type of Waste } & \multicolumn{2}{c}{ Gram/people/day } \\
\cline { 2 - 3 } & Gross Weight & Dry Weight \\
\hline Stool & $135-270$ & $35-70$ \\
Urine & $1.000-1.300$ & $50-70$ \\
\hline Amount & $1.135-1.570$ & $85-140$ \\
\hline Source : [9] & \multicolumn{2}{c}{}
\end{tabular}

The implementation of fecal waste management is closely related to environmental and public health problems. The decrease in water quality and sanitation quality caused by the disposal of human feces can be overcome, eliminated, suppressed or reduced if the factors causing the problem are reduced in content, kept away from human contact.

In the operational implementation of the sewage treatment plant, there are several obstacles faced by the City of Surabaya in the implementation of technical activities. Some identification of problems faced by the City of Surabaya are as described in table 4.

Table 4. Identification of Problems in the Faecal Waste Management Process in Surabaya City

\begin{tabular}{ccc}
\hline No & Aspect & \multicolumn{1}{c}{ Identification of Problems } \\
\hline 1. & Technical Aspects & $\begin{array}{l}\text { - Repair of several processing } \\
\text { ponds and supporting } \\
\text { buildings at the IPLT } \\
\text { location needs to be carried } \\
\text { out immediately if the } \\
\end{array}$ \\
& operation of the IPLT is to be
\end{tabular}




\begin{tabular}{|c|c|c|}
\hline No & Aspect & Identification of Problems \\
\hline 2. & Social Aspect & $\begin{array}{l}\text { optimized; } \\
\text { - There is a need for strict } \\
\text { supervision and control } \\
\text { regarding disposal SOPs } \\
\text { from feces trucks to IPLT; } \\
\text { - There needs to be an } \\
\text { evaluation of the operational } \\
\text { feasibility conditions of the } \\
\text { Keputih IPLT. } \\
\text { Public awareness is still very } \\
\text { lacking in efforts to service } \\
\text { household desludging, with the } \\
\text { reason that the cubluk / septic } \\
\text { tank is not full and has never } \\
\text { leaked. }\end{array}$ \\
\hline 3. & $\begin{array}{l}\text { Institutional } \\
\text { Aspect }\end{array}$ & $\begin{array}{l}\text { - It is necessary to allocate } \\
\text { funds in the framework of } \\
\text { managing waste water } \\
\text { management at the relevant } \\
\text { Office; } \\
\text { - The legal aspects related to } \\
\text { the management of sludge } \\
\text { in the city of Surabaya only } \\
\text { regulate the issue of service } \\
\text { retribution. Substances } \\
\text { governing socialization and } \\
\text { calls for sucking up sludge } \\
\text { in septic tanks and } \\
\text { household cubes have not } \\
\text { been regulated. } \\
\text { - Remodeling \& optimization } \\
\text { costs for Keputih IPLT are } \\
\text { needed. } \\
\text { - Increasing the capacity and } \\
\text { quality of human resources } \\
\text { in the field of wastewater in } \\
\text { the environment is very } \\
\text { necessary. }\end{array}$ \\
\hline
\end{tabular}

Source : [4]

In order for the management of urban fecal waste to take place optimally, the management system must have 4 (four) main elements, namely: 1) control of the septic tank, 2) desludging of the septic tank, 3) transportation of fecal waste and 4) treatment of fecal waste. Where, these elements are interconnected and interact with each other and work together to get the goals and objectives set. In the management of fecal waste, the constituent elements are not only the processing units and physical waste disposal facilities, but also include non-physical elements such as management, HR competencies, standard information and procedures for the management of stool waste as a whole..

Surabaya City itself already has sewage treatment facilities, but as described in the previous section there are still many obstacles faced. The results of the treatment of fecal waste carried out at the Whitewater Waste Treatment Plant (IPLT) of Surabaya City are still not yet perfect. The main obstacle in the processing is the lack of stool waste supply so that the processing process is not optimal.

One of the factors to support the success of fecal waste management in the city of Surabaya is the existence of an active community role. Most of the problems of fecal waste management lead to people's daily life / activities.
This problem is usually caused by the handling of stools that are not yet sanitary so that the surrounding dwelling places have unpleasant views and odors, an increase in the population of flies and mosquitoes, the emergence of cases of gastrointestinal diseases endemic or epidemic.

\section{Conclusion}

Efforts that can be made to overcome the problem of waste management need to be done on understanding the various factors that cause problems in the management of fecal waste. In general, the three main factors that hinder the process of managing sewage in the city of Surabaya are due to: (1) lack of sludge supply; (2) lack of public awareness of the resulting stool waste; and (3) regulations that have not been regulated related to desludging regularly.

These three things have a very close relationship in succeeding the waste management of the city of Surabaya. The existence of regulations that can increase the knowledge of the Surabaya City community on the importance of draining the septic tank will certainly have a positive effect, one of which is to produce enough sludge supply to be processed in the Keputih IPLT.

The implementation of fecal waste management is closely related to environmental and public health problems. The decrease in water quality and sanitation quality caused by the disposal of human feces can be overcome, eliminated, suppressed or reduced if the factors causing the problem are reduced in content, kept away from human contact [2]. in addition, urban sludge management and the construction of a Fecal Management Plant (IPLT) are also one of the indicators contained in the Sustainable Development Goals which are on indicators 6.3.1 (a) so that it needs to be a concern for the government and society.

Utilization of the Fecal Treatment Plant can reduce the problem of water pollution caused by fecal waste and can indirectly improve the quality of environmental sanitation. In addition, there is a need for community understanding of the importance of managing stool waste produced so that acts of polluting the environment and the need for the role of the Regional Government to create services and the existence of regulations that can be used as a basis for the management of fecal waste.

One of the breakthroughs that can be done by the Surabaya City Government is to make scheduled sludge desludging services / scheduled sludge service. This program is one of the breakthroughs that can be carried out by the Surabaya City Government to provide desludging services from septic tanks owned by the community and carried out periodically. In this service, desludging is carried out according to the desludging period and the specified desludging schedule.

Based on the calculation of the number of population and accumulation of sludge produced by each person per year, the potential for the generation of sludge that should be treated in the sludge treatment plant (IPLT) is quite high. But in reality, the volume of sludge that is processed in the sludge treatment plant is very minimal, so that $90 \%$ of the built-in sludge treatment plant experiences 
considerable idle capacity. This relates to the quality of local system facilities that do not meet the standards and services of sludge desludging which are still based on consumer demand (on call based)[10].

To overcome the problem of idle capacity in the sludge treatment plant and optimize the processing of local wastewater which aims to overcome the problem of environmental degradation caused by wastewater and fecal waste, it must be carried out regularly by desludging. Scheduled Sludge Services is a system developed to carry out sludge desludging activities that are carried out periodically or scheduled on local and communal wastewater management systems, which are then processed in treatment plants owned or determined by the Government where these services are also related with the predetermined payment method [10].

By implementing scheduled sludge services, the Surabaya City Government will receive direct benefits as follows: $\square$

a. Control of the condition and performance of the septic tank in its user buildings.

b. Reduced potential for environmental pollution which will then improve the level of public health.

c. The creation of better operability of sludge treatment infrastructure.

d. Increasing regional income more continuously. While the indirect benefits of scheduled sludge services that can be obtained by the Surabaya City Government are: $\square$

a. Increased public awareness of their responsibilities and obligations in managing domestic wastewater produced.

b. Usually the community starts to have financial responsibility for the waste water it produces.

c. Triggering improvements in other sludge management components, especially regarding the quality of septic tanks and sludge treatment.

d. The opening of other business opportunities related to the use of latrines and waste water management.

e. Improving the image of the city as a region that performs waste water management is better than other cities.

\section{Reference :}

1. Badan Pusat Statistik, Kota Surabaya dalam Angka 2017. Surabaya, (2017).

2. H. M. Soeparman and Suparmin, Pembuangan Tinja dan Limbah Cair : Suatu Pengantar. Jakarta: Penerbit Buku Kedokteran EGC, (2002).

3. Dinas Lingkungan Hidup Kota Surabaya, "Informasi Kinerja Pengelolaan Lingkungan Hidup Daerah,” Surabaya, (2017).

4. UPTD IPLT Keputih, "Laporan IPLT Keputih Kota Surabaya Propinsi Jawa Timur," (2010).

5. G. Dian and W. Herumurti, "Evaluasi Kinerja Instalasi Pengolahan Lumpur Tinja (IPLT) Keputih," vol. 5, no. 1, pp. 1-6, (2016).

6. Dinas Kesehatan Kota Surabaya, "Laporan Akhir Studi Environmental Health Risk Assessment ( EHRA ) Kota Surabaya," (2015).

7. A. Azwar, Pengantar Ilmu Kesehatan. Jakarta: Mutiara Sumber Widya, (1995).

8. H. B. Gotaas, "Composting; sanitary disposal and reclamation of organic wastes.," Monogr. Ser. World Health Organ., no. 31, pp. 1-205, (1956).

9. E. G. Wagner and J. N. Lanoix, "Excreta disposal for rural areas and small communities.," Monograph series. World Health Organization, vol. 39. pp. 1-182, (1958).

10. Kementerian Pekerjaan Umum, "Pedoman Layanan Lumpur Tinja Terjadwal," Jakarta, (2014). 